\title{
Editorial
}

\section{Tempo de Ação para a Escola Médica}

\section{Time to Action to Medical School}

Sergio Rego

Em 1990, enquanto exercia a funçao de diretor executivo da Abem na gestão do professor Frederico Simões Barbosa, vivíamos numa conjuntura sociopolítica e econômica das mais complexas para o ensino médica no país. Havíamos, em conjunto com as demais entidades médicas nacionais e outras associaçōes, como a Abrasco, recém-conseguido a edição de uma norma regulamentadora para a criação de escolas na área da saúde, condicionando-a ao cumprimento de uma série de exigências, entre as quais a aprovaçăo do Conselho Nacional/Estadual de Saúde. Na época, essa preocupação se estendia ao estabelecimento de obstáculos à criação indiscriminada de escolas médicas (percebida sempre como um ótimo negócio, tanto econômica como politicamente). Embora a regulamentaçăo tenha sido feita, a criatividade dos interessados em desrespeitá-la encontrou caminhos para burlá-la e possibilitar este novo boom de escolas médicas que observamos no final do século.

O então presidente Fernando Collor havia sido recém-empossado, e delineava-se uma política muito pouco favorável ao ensino superior, particularmente, mas não só, nas universidades federais. $\mathrm{O}$ novo governo esboçava uma política para a educação superior que, em nome de uma suposta maior eficiência, apontava para o enfraquecimento/sucateamento das escolas públicas em beneficio do setor privado. Não apresentava planos concretos, mas a retórica sugerida nos discursos apontava para o estímulo à iniciativa privada com o objetivo de ampliar sua participação no ensino superior.

O Cremesp buscava caminhos legais para instituir o "exame de ordem", à semelhança do que existe até hoje na Ordem dos Advogados do Brasil, procurando estabelecer barreiras de acesso ao mercado de trabalho paulista a médicos formados em outros estados, segundo me declarou em entrevista gravada seu então presidente. Considerava que, como a escola médica em geral formava profissionais com baixa qualificação, competiria aos Conselhos regular sua entrada no mercado de trabalho formal. O governo federal divulgava na imprensa sua intenção de incorporar esta idéia como política de governo.

$\mathrm{Na}$ época, tive a oportunidade de escrever um Editorial do Boletim da Abem no qual dizia algo como: ninguém é contra a avaliaçăo das escolas, mas queremos que esta avaliação seja tecnicamente competente do ponto de vista educacional e que haja transparência no processo. Afirmava que nåo poderíamos aceitar a satanização das escolas médicas em nome de interesses espúrios não manifestos. Procurei expressar o que era o sentimento predominante, se não em todas as escolas médicas na época, mas ao menos entre os diretores da Abem e seus coordenadores regionais. No Congresso Brasileiro de Educaçăo Médica realizado em Cuiabá naquele ano, tomou posse a diretoria eleita com o professor Benedictus Philadelphus e teve início o processo que culminou com a criação da Cinaem.

A despeito das falhas de método no que se convencionou chamar de primeira fase da Cinaem, o processo de avaliação ganhou o apoio político da maioria das escolas médicas do país e fomentou um crescente amadurecimento das escolas em relação ao papel da avaliação na educação. A disseminação da cultura avaliativa é, no meu entender, um, dentre outros, dos grandes méritos da Cinaem. Saímos de uma fase em que muito poucos efetivamente dominavam o tema e chegamos hoje a uma situação em que a reflexão crítica foi disseminada. Esta disseminação, entretanto, não é uniforme entre as diversas escolas, nem, muito menos, nos quadros docentes e discentes da maioria das escolas.

Outro ponto a destacar no processo de avaliação desencadeado através da Cinaem foi a efetiva mobilização de um expressivo número de escolas para participar do debate e implementar, com maior ou 
menor significado, os instrumentos preconizados pelo coletivo. Esta mobilizaçăo foi um dos fatores que permitiu à Abem, já na gestão da professora Regina Stella, intensificar o processo de descentralizaçăo com o fortalecimento das instâncias regionais da Associação, bem como reforçar o engajamento dos estudantes na Associação através da paridade nos cargos representativos.

Neste período, verificamos também o início de processos de transformação curricular e de modelos de ensino em algumas faculdades do país. Foi o caso das escolas médicas de Londrina, Marília e outras que estão num processo menos avançado e que têm em comum a relação com o chamado projeto UNI. A vinculação dessas escolas com o fenômeno social Cinaem se deu em intensidades diferentes e, até mesmo, em momentos diferentes, assim como sua própria inserção no projeto UNI. Além do apoio financeiro que o projeto conferiu às escolas participantes para deflagrarem seus processos de transformação, é possível especular que um certo grau de independência do processo coletivo que vinha se dando no seio do Projeto Cinaem tenha contribuido para os avanços mais significativos que hoje podem ser comprovados. Ou seja, isto corroboraria a idéia de que os processos de mudança são singulares, ainda que inseridos num amplo espaço coletivo de debates. Nesta lógica, a escola que tivesse esperado o avanço do processo coletivo ou seguido tăo-somente os consensos obtidos naquele fórum teria a sua dificuldade de mudar explicada por seu próprio padrão de atuação.

Ao longo deste periodo de mais de dez anos, a conjuntura nacional não foi inteiramente favorável. Se por um lado as iniciativas de avaliação externa, originárias do poder público federal, mantiveramse distantes da escola médica durante a maior parte do período, por outro, a recusa em divulgar publicamente os resultados individualiza. dos da avaliaçăo realizada pela Cinaem levou o governo a incluir a Medicina entre as carreiras que seriam submetidas a avaliação coordenada pelo Inep. O processo de globalizaçăo da economia tornou cada vez mais inevitável a formalizaçăo do acordo da Alca ou, pelo menos, a consolidação do Mercosul com a integração de mercados e a urgente definição de critérios e processos de validação de diplomas entre os países membros. Começou-se, também, a discutir o processo de acreditação de escolas e, embora tenham participado diversas entidades representativas médicas, há indícios de que o governo federal pretende atribuir a função a um de seus órgãos.

Finalmente, no ano passado, tivemos a publicação das Diretrizes Curriculares Nacionais, que romperam, năo sem riscos, com o modelo ultrapassado do currículo mínimo, e, este ano, da primeira iniciativa governamental diretamente relacionada com o estímulo ao processo de transformaçāo das escolas médicas, através de um programa que incentivará, com repasses financeiros e acompanhamento técni$c o$, os processos de mudança nas escolas selecionadas entre as interessadas. O governo federal indicou, através de um edital, o modelo de escola médica que deseja: inserido no Sistema Único de Saúde, com ênfase na assistência básica e na promoção da saúde, utilizando métodos de ensino que valorizem o estudante como sujeito de seu processo de aprendizagem e comprometido com a educação permanente. A adesão ao modelo é voluntária, mas a política de governo só financiará aqueles interessados e comprometidos com esse modelo.

Os artigos publicados neste número da RBEM mostram que tal modelo não está distante das preocupaçoes e da atenção de uma grande diversidade de escolas médicas. Selecionados estritamente de acordo com a data de aprovação pelo Conselho Científico, eles refletem a preocupação presente nas escolas com a humanização da assistência, enfoque na promoção da saúde e avaliação pelos discentes.

Embora tanto já tenhamos avançado, muito ainda resta a fazer. Muitas escolas médicas sequer participaram da Cinaem. Dentre as que participaram e participam do movimento de avaliação do ensino médico, várias não apresentam avanços significativos em seus pro. cessos internos de mudança.

Não creio ser paranóico afirmar que os sinais de crise na assistência médica - em especial a deterioração nas relaçōes entre profissionais de saúde e pacientes; a morosidade com que se processam as mudanças nas escolas em geral; a necessidade de preparar profissionais capacitados para atuarem nos primeiros niveis de atençăo; e o caráter aparentemente inevitável de integração dos mercados regionais, seja pelo Mercosul, seja pela Alca - podem conformar uma situação em que o próximo governo, seja ele qual for, tenha que intervir no credenciamento para a vida profissional, retirando, ou relativizando, a competência exclusiva que até hoje as corporaçōes profissionais detêm (através das escolas e conselhos).

Todo processo de planejamento encontra na execuçăo seu momento mais dificil. É o momento de permanentemente reavaliar o processo, readaptar suas estratégias e redefini-lo. É hora de fazermos isso. Não podemos ficar eternamente em reunioes discutindo o processo e não iniciá-lo efetivamente em cada escola. Temos que aproveitar o momento, ainda favorável às iniciativas originárias de cada escola e, assumindo nossa responsabilidade social, compreender o processo como uma necessidade inadiável. Antes que a sociedade considere que isso nunca será feito e imponha uma espécie de filtro na saída das universidades ou na entrada do mercado de trabalho, a exemplo do que já existe em tantos países que, como o nosso, tem os Estados Unidos como principal modelo. 